\title{
Food Security and the Right to Food: Finding balance in the 2012 Food Assistance Convention
}

\author{
Annamaria La Chimia*
}

\begin{abstract}
On 25 April 2012, after years of negotiations delayed by halts and set-backs, the Food Assistance Convention was adopted -the latest in a series of agreements that since 1967 have regulated the international provision of food aid. Great expectations have been placed on the adoption of the Convention. In particular it was hoped that the Convention would answer the call for a new system of food aid governance, introduce more effective mechanisms to address world's food insecurity and, ultimately, improve and modernise the rules applicable to food aid. This paper provides the first critical commentary of the Convention's text, assesses the strengths and weaknesses of its provisions and considers whether and how the Convention has modified the architecture of international food aid regulation. The paper also indicates where amendments to the rules might be needed to make the international regulation of food aid more effective. The paper concludes that the Convention is, on balance, a positive instrument that could improve governance and adequacy of food assistance. The Convention is also important for the international human rights discourse on how States can fulfil their obligation to assist countries in need in that it offers guidance on how to meet such obligation in the specific context of the right to food. States should therefore be urged to sign and ratify it.
\end{abstract}

Keywords: Food Aid, Food Assistance, Food Assistance Convention, Food Security, Right to Adequate Food

\section{INTRODUCTION: INTERNATIONAL REGULATION OF AN IMPERFECT TOOL TO FIGHT HUNGER}

For the past 60 years food $\mathrm{aid}^{1}$ has been one of the instruments used to tackle hunger and food insecurity around the world. ${ }^{2}$ However, the provision of food aid and its use are often

\footnotetext{
* Associate Professor, School of Law, University of Nottingham, email annamaria.lachimia@nottingham.ac.uk I would like to express my heartfelt thanks to Professor George-Andre Simon for the lively discussions on many of the ideas presented in this paper and for his many suggestions and advice on this paper in draft. I would also like to express my gratitude to Professor Therese Murphy for reading and commenting on this paper in draft and to Dr Edward Clay for discussing with me some of the issues here analysed. I would also like to thank the reviewers of this paper for their thorough comments and suggestions. Finally, I am grateful to the British Academy for funding part of the research necessary for completing this article. The usual disclaimers apply.

${ }^{1}$ Food aid is defined as 'commodities provided by international donors on concessional terms,' see WFP, 'Food aid information system' available at: www.wfp.org/fais/quantity-reporting/glossary accessed 1 August 2013. As Barrett and Maxwell argue three elements characterise food aid: the international sourcing (so national food schemes, such as food vouchers, are not part of food aid); the concessionality of the financing (with a minimum grant element of 80 per cent); and the fact that it can be 'in the form or for the provision of food,' C Barrett and D Maxwell, Food Aid After Fifty Years: Recasting its Role (Routledge 2006). The term food assistance has recently emerged and for some it better reflects the variety of options available to donors when aiding beneficiary countries (see further section 2). In this paper both the term food aid and food assistance will be used, the former will be preferred when referring to the period preceding the Convention. No agreed definition of food assistance currently exists.

${ }^{2}$ Food insecurity exists when people don't have physical and economic access to sufficient, safe and nutritious food to meet their dietary needs and food preferences for an active and healthy life. Food insecurity can be
} 
questioned: the positive effects of food aid, - its lifesaving nature, its capacity for meeting people's right to food and to be free from hunger- are often outweighed by its costs. ${ }^{3}$ Yet with more than 1.7 billion people suffering from malnutrition food aid still plays a critical role in alleviating the suffering of starving people ${ }^{4}$ and, as Clapp argues, although 'it is by no means the primary response or the best approach to ensuring food security. Nevertheless, some 150200 million people depend on it every year. ${ }^{5}$ No critic would argue for the abolition of food aid; ${ }^{6}$ rather, experts concur on the need to enhance its effectiveness and foster its success. In the past decade a consensus has emerged to reconsider the way food aid is used, distributed and procured and to redefine and redesign the international architecture of food aid donations, including the rules applicable to the granting of food aid.

Since the mid-sixties the most important international instrument regulating the provision of food aid has been the Food Aid Convention (FAC), the only binding international agreement between major donors of food aid first concluded in 1967 as part of the International Grains Agreement, ${ }^{7}$ and renegotiated at regular intervals since then (in 1971, 1980, 1986, 1995 and, lastly, in 1999. ${ }^{8}$ )

The importance of the FAC has been widely recognised and its provisions have been recalled by other international agreements (for example article 10 of the WTO Agreement on Agriculture refers expressly to some of the commitments endorsed by members of the FAC. ${ }^{9}$ ) It has been praised for being the sole international agreement to establish a framework of cooperation that 'binds donors to minimum commitments of aid donations' 10 and to set boundaries on the use of food aid as a means of export promotion. ${ }^{11}$ In the wider aid context its importance is linked to its being a unique example of aid regulation -being the only international agreement to set binding rules on both the quantum (ie. the financial question linked to how much assistance should be provided) and the quomodo (ie. in what ways the assistance should be provided ) of aid obligations.

However, over time much criticism has also been raised against the FAC. In particular, commentators have criticised the FAC governance system and institutional settings, including: the lack of developing countries' representation in the conventions and their

chronic or transitory. Chronic food insecurity is a long term or persistent inability to meet minimum food requirements, transitory food insecurity is a short term or temporary food deficit. See www.wfp.org

${ }^{3}$ The literature on the negative consequences of food aid is vast, see for all Barrett and Maxwell (n 1). See also E Clay and O Stokke (eds), Food Aid and Human Security (Frank Cass, 2000)

${ }^{4}$ See $\mathrm{O}$ De shutter, 'The role of development cooperation and food aid in realising the right to adequate food: moving from charity to obligation', ref. A/HRC/10/005, March 2009

5J Clapp, Hunger in the Balance: The New Politics of International Food Aid (Cornell University Press 2012), the author also acknowledges that 'in situations of acute food shortages... such aid can mean the difference between life and death'

${ }^{6}$ Barrett and Maxwell (n 1)

${ }^{7}$ Adopted along with the Grains Trade Convention.

8 The 1999 FAC originally expired in 2002 but it was renewed through yearly extensions for almost ten years At the $106^{\text {th }}$ session of the Food aid Committee members agreed not to extend the 1999 FAC which was finally allowed to expire on 30 June 2012. See http://www.foodaidconvention.org/en/Default.aspx accessed 5 December 2013

${ }^{9}$ Article 10.4 of the WTO Agreement on Agriculture makes reference to the Food Aid Convention and requires aid to be donated fully in grant form (to the extent possible) or on terms no less concessional than those provided under the FAC (ie with a minimum concessionality level of 80 per cent). As Clapp argues this reference is important because now all WTO members (so not just FAC members) are in effect required to refer to the FAC terms. See Clapp (n 5)

${ }^{10}$ Clapp (n 5)

${ }^{11} \mathrm{Ibid}$ and Barret and Maxell (n 1) 
exclusion from the work of the FA Committee (the Convention's governing body ${ }^{12}$ ); the lack of transparency in the operation of the FA Committee which weakened its impact on the global food security debate; ${ }^{13}$ the weaknesses of commitments endorsed by FAC members and in particular the many loopholes in the conventions system which allow donors to easily forsake their obligations; the inadequacy of the FAC monitoring and enforcement mechanisms and the absence of evaluation procedures to assess the impact that members' commitments have on recipient countries. ${ }^{14}$ More recently, critics have also spoken of the 'fading legitimacy of the $\mathrm{FAC}^{\prime 15}$ because of its ineffectiveness as a mechanism to guarantee appropriate levels of food aid during the 2008 food price crises.

When the termination date of the 1999 FAC approached, food aid experts saw, in the (expected) process for renegotiating the agreement, an opportunity to address this criticism, to modernise the rules applicable to food aid and to address the shortcomings of the system of food aid donations built within previous agreements. Debates on the renewal of the FAC branched into several discrete areas: they focused on key issues of governance (within the FAC itself and within the broader food security context ${ }^{16}$ ); included discussions on whether a new convention was at all needed; ${ }^{17}$ and covered topical aspects of food aid effectiveness with the view to address some of the long-standing problems associated with food aid donations, in particular ensuring that food aid is geared towards food security. ${ }^{18}$

Negotiations for a new convention first started in 2002 when the 1999 FAC originally expired but they were deferred pending the outcome of the negotiations on food aid conducted under Art 20 of the WTO Agreement on Agriculture (AoA) as part of the WTO Doha Development Round (DDR). The 1999 FAC was in the meanwhile renewed through yearly extension. Talks to initiate consultations for a new Convention reopened in 2008, when the WTO negotiations stalled and it was clear that WTO members had failed to reach a conclusive agreement. ${ }^{19}$ In 2010 a working committee of the International Grains Council ${ }^{20}$ (IGC) was

\footnotetext{
12 The FA Committee is i.e. the forum where rules elaborating further the provisions of the Convention are adopted and where information sharing and discussion with other stakeholders is facilitated (see art 7.3 and art 7.6 of the Convention). All Parties to the Convention are members of the FA Committee. For a critique of the FA Committee and the lack of beneficiaries' and NGOs' representation see J Hoddinott and M J Cohen, 'Renegotiating the Food Aid Convention' (IFPRI, April 2007).

${ }^{13}$ see J Hoddinott, M J Cohen and C Barrett, 'Renegotiating the Food Aid Convention: Background, Context, and Issues' (2008) 14 Global Governance 283.

${ }^{14}$ For an extensive analysis of this point and a thorough critique of the 1999 FAC see ibid.

15 J Clapp and S Clark, 'Improving the governance of the Food Aid Convention: which way forward?' (2010) The Centre for International Governance Innovation, Policy Brief n. 20.

${ }^{16}$ i.e. how to improve governance within the FAC and how 'the FAC can fit into the broader global food security governance framework' see Ibid. The broader question of governance included discussions over how the FAC should integrate with other international organisations also dealing with food security

${ }^{17}$ E Clay, 'A Future Food Aid or Food Assistance Convention?' (ODI Background Paper on Food Aid No. 6, July 2010) ( http://www.odi.org.uk/sites/odi.org.uk/files/odi-assets/publications-opinion-files/6040.pdf)

${ }^{18}$ See for all J Hoddinott, M J Cohen and C Barrett (n 13)

${ }^{19}$ Modalities for a new text of the AoA have been concluded in 2008 [See WTO Committee on Agriculture, 'Revised Draft Modalities for Agriculture-Sensitive Products: Designation' (6 December 2008) WTO Doc TN/AG/W/4/Rev.4] these contained, in Annex L, profuse provisions on food aid. While at the latest Ministerial Conference in Bali (7 December 2013) the 2008 Modalities have not been adopted, WTO members agreed that they remained 'important basis for future an ambitious final agreement in the export competition pillar' Document WT/MIN(13)/W/12 Page 1.

${ }^{20}$ Since 1967 the IGC has acted as the FAC host agency and secretariat.
} 
established and FAC members ${ }^{21}$ agreed to begin the formal process of renegotiating the 1999 FAC. At its opening meeting the IGC working group declared that 'the process [of negotiations] would start with immediate effect and involve a period of intensive negotiations and further consultations over the coming months with the aim of drafting a new convention committed to providing appropriate and effective food assistance to vulnerable populations in response to needs' (emphasis added). ${ }^{22}$ After two years of negotiations, on 25 April 2012, the Food Assistance Convention was adopted ${ }^{23}$ (hereafter the Convention). The Convention replaces the 1999 FAC but it is an independent agreement. ${ }^{24}$ It entered into force on $1^{\text {st }}$ January 2013 , following the deposit of the instruments of ratification acceptance or approval by six of its signatory Parties. ${ }^{25}$

Whilst signatories to the Convention include most countries who were previously members $^{26}$ of the 1999 FAC, ratification however remains slow. Members of the 1999 FAC who did not sign the Convention by $31^{\text {st }}$ December 2012 and have not yet done so (for example Italy, Germany and the UK) can accede to it at any time. ${ }^{27}$ Countries who were not previously members of the FAC have been able to join the Convention since it entered into force. ${ }^{28}$ For instance, the Russian Federation, an important new donor of assistance, joined on 3 April 2014. For the first time since 1967, the Convention has not set a termination date but will be in force until Parties agree otherwise. ${ }^{29}$

Has the opportunity to ameliorate the rules applicable to food aid been seized by the drafters of the Convention? Has the provision of food aid been improved and modernised as

\footnotetext{
${ }^{21}$ Members of the 1999 FAC were Argentina, Australia, Canada, the European Union and its member countries, Japan, Norway, Switzerland, and the United States.

${ }^{22}$ Food Aid Committee, 103 ${ }^{\text {rd }}$ Session held on 14 December 2010, London, Press Release, 20 December 2010 〈http:// www.foodaidconvention.org/Pdf/p r/prfacdec10.pdf) accessed 5 December 2013.

${ }^{23}$ Depositary notification C.N.215.2012. Electronic copies of the Convention are posted on the United Nations Treaty Collection Website at http://treaties.un.org/doc/source/signature/2012/CTC XIX-48.pdf ${ }^{24} \mathrm{FAC}$ Chair's Presentation at WFP Executive Board, 6 June 2013, available at http://www.foodassistanceconvention.org/pdf/general/FAC Presentation WFP June13.pdf accessed on 5 December 2013. Albeit an independent agreement the Convention follows within the stream of the Food Aid Conventions that since 1967 have regulated the provisions of food aid. Indeed the International Grains Council remains the Assistance Convention's host agency and secretariat (based in London), the objectives of the 1999 FAC are expressly endorsed by the new agreement (see preamble, paragraph 1 of the Assistance Convention), the procedures for accession for members of previous FAC and for new members are different (see art 13 discussed infra).

${ }^{25}$ According to art 15, the Convention would enter into force on 1 January 2013 if by 30 November 2012 five Signatories have deposited instruments of ratification, acceptance or approval. Japan was the first country to sign the Convention and to deposit the instruments for acceptance (24 th July 2012) followed by the US (acceptance), Switzerland (ratified), Denmark (approval), Canada (ratified), the European Union (approved), Finland (acceptance) Austria (ratified) Luxembourg (ratified), Australia (ratified). Recently, the Russia Federation, Slovenia and Sweden have acceded on 3 April 2014, 8 May 2014 and 12 May 2014 respectively. Other participants who have signed but have yet to ratify the Convention include Bulgaria, France, Greece, and Portugal.

${ }^{26}$ The words Members of the 1999 Convention and Parties of the Assistance Convention are used to reflect the different terminology employed by the two Conventions.

${ }^{27}$ Art 13(1) of the 2012 FAC.

${ }^{28} \mathrm{Art} 13(2)$ of the Convention. This now includes important new donors of food assistance such as India, Brazil, the Republic of Korea, South Africa.

${ }^{29}$ According to art 17 of the Convention any Party can propose the termination of the Convention at any time after its entry into force. As further explained below, the indefinite nature of the Convention might be one of the reasons why the Convention departs from previous conventions on the way Parties' agree (and now can modify) their commitments.
} 
a result of its adoption? This article assesses whether and in what ways the Convention has addressed the criticism raised against the framework for food aid donations embedded within previous FACs and how it has modified the architecture of international food aid regulation. ${ }^{30}$ The analysis will also offer the opportunity to reflect on what role the Convention could play on the global food security debate and how the Convention could improve food assistance governance. Comparisons with previous Food Aid Conventions will be made to help clarify the extent of the innovations introduced. Suggestions will be made on where amendments to the new rules might be needed to make the international regulation of food aid more effective and to attain the Conventions' objectives.

After this introduction the article is divided into three sections. Section 2 is dedicated to the investigation of the Conventions' scope and coverage. The analysis starts in sub-section A with an assessment of the Convention's objectives and their impact on the expansion of the Convention's scope, including its relevance for the debate on how states can fulfil their human right obligation to assist food insecure countries. It then moves in subsection B to consider the significance of the name change, asking whether the new name signals the endorsement of a new ethos governing the relationship between Parties to the Convention and beneficiaries of assistance and to what extent the new ethos is embraced into a new system of food aid governance within the Convention. ${ }^{31}$ To this end the Convention's institutional arrangements, including the Convention's new rules on membership and participation in the work of the FA Committee will be investigated. The analysis will then continue with an assessment of the Convention's coverage (sub-section C), looking in particular at the quantum (intended as both quantities and values of Parties' commitments) and the quomodo of Parties' obligations (i.e. how aid should be provided, for example in grant form, untied etc.). Significant innovations have been introduced by the Convention on the way Parties set (and now modify) their commitments and on the way they will deliver food assistance. Reference to the monitoring and enforcement mechanisms provided by the Convention will then be made to understand how these mechanisms will affect the implementation of the Convention's provisions. Section 3 will consider the controversial issue of the relationship with the WTO. It will be here explained what innovations have been introduced by the Convention in this area, revealing the potential implications of the new provisions for the global food security debate. Section 4 will conclude arguing that, on balance, the Convention is a positive instrument that should be ratified by as many countries as possible. It is the only legal instrument to offer specific guidance on how States can fulfil their international human right obligation to assist countries in need in that it offers guidance on how assistance should be provided in the specific context of realizing the right to adequate food. Its implementation could improve governance of food assistance, especially thanks to its transparency provisions and the enhanced participation of NGOs and beneficiary countries to the work of the FA Committee and could enhance the effectiveness of food assistance.

\footnotetext{
${ }^{30}$ Such analysis is necessary given the ambiguity of some of the Convention's provisions and the gap in the existing literature.

${ }^{31}$ Two different aspects of the question of governance have been identified by scholars namely governance within the FAC and governance within the wider food security context, Clapp and Clark provide the clearest account of the question of governance which they identify in: "how the FAC can fit into the broader global food security governance framework and how to improve the performance of the more technical governance functions carried out by the FAC.' It is on the latter aspect that this paper first focuses. As Clapp and Clark argue 'the governance arrangements of the FAC are essential for its overall performance.' See Clapp and Clark, (n 15)
} 


\section{FROM THE FOOD AID CONVENTION TO THE FOOD ASSISTANCE CONVENTION: A NEW ERA FOR THE REGULATION OF FOOD DONATIONS?}

A. Setting the frame for discussion: the Conventions' new objectives and their implication for Parties' obligations

Since its first inception the FAC has envisaged a framework of cooperation between donors (producers and, for the vast majority, exporters of food) to provide minimum amounts of food aid to beneficiary countries in need (the so-called minimum commitment). This original framework has embedded all the conventions that followed and is still an essential feature of the Convention. However, while the original FAC, mirroring members' ambivalent use of food aid as a tool to face world's hunger and as a means to promote food exports and dispose of surplus stock, ${ }^{32}$ focused mainly on the quantum of members' commitments (i.e. how much food aid should be donated) with members agreeing to specific quantities of food aid donations, ${ }^{33}$ later conventions (especially those agreed in the nineties) paid greater attention to food security and to the quomodo commitments (i.e. the ways in which aid should be donated), ${ }^{34}$ with a view to make food aid more effective. These quomodo commitments however remained weak, mainly drafted in terms of best-effort endeavours and relevant only for donations made in furtherance of FACs' commitments.

The Convention focuses firmly on food security showing a mature understanding of its causes and effects. ${ }^{35}$ Food security is now inextricably linked with nutrition and with the longterm rehabilitation and development objectives of the beneficiary countries. ${ }^{36}$ Significantly the Convention, for the first time, recognises States' responsibility in the progressive realization of the right to adequate food and to be free from hunger (via reference to the 2004 FAO Voluntary Guidelines ${ }^{37}$ ) therefore unambiguously linking food assistance to the realisation of such right. Reference to the right to food is important because it opens the possibility of interpreting the provisions within the Convention through a Human Rights lens and to question whether the assistance provided is apt to fulfil that right. At the same time, as the Convention is the first and only instrument that lays detailed rules on how assistance should be provided it becomes relevant for the broader human rights context of how states' fulfill their human right obligation to 'assist' countries in need. Although States' obligation to assist is now recognized (albeit not without controversy) as a principle of international human rights law for all Economic, Social and Cultural Rights, ${ }^{38}$ its exact confines remain uncertain

\footnotetext{
${ }^{32}$ As Clapp argues, the adoption of the first FAC was motivated by the desire of its members to regulate and impose some limits to the use of food aid as a means to dispose of surplus stocks whilst guaranteeing minimum quantities of food aid to countries in need, Clapp (n 5)

${ }^{33} \mathrm{FAC}$ Chair's Presentation at WFP Executive Board, 6 June 2013, < http://www.foodassistanceconvention.org/pdf/general/FAC Presentation WFP June13.pdf /

${ }^{34}$ For example whether food aid should be donated as grants or loans, whether tied or untied, where it should be procured etc.

35 para 1 of the preamble of the Convention and art. 2.

${ }^{36}$ Art 2(a) and 2(c)

${ }^{37}$ Para 4 of the preamble of the Convention. Curiously the Convention refers to the FAO principles rather than to the International Covenant on Economic Social and Cultural Rights where this right was first enshrined (this is probably due to the fact that the US, one of its primary signatories, has yet to ratify the ICESCR).

38 Its biding nature is for many to be inferred from a conjunct reading of the UN Covenant on Economic, Social and Cultural Rights and art 55 and 56 of the UN Charter See O De Schutter, A Eide, A Khalfan, M Orellana, M Salomon, I Seiderman, 'Commentary to the Maastricht Principles on Extraterritorial Obligations of States in the area of Economic, Social and Cultural Rights' (2002) 34 Human Rights Quarterly 1084 and for all M Salomon, 'The
} 
(i.e. the quantum and quomodo issues of aid have never been set in binding legal instruments ${ }^{39}$ ) and are mostly still at the discretion of each state. The Convention helps define such obligation by committing States Parties to the Convention to donate a certain amount of assistance (the quantum issue) in a certain way (the quomodo issue). Such position is reinforced by the fact that some of the Convention's principles are now of broad application, ${ }^{40}$ not confined to the assistance donated under the Convention (i.e. to the minimum commitments) but applicable to all assistance provided by Parties, therefore important for Parties' food assistance practices in general. ${ }^{41}$ Hence the Convention helps moving forward the Human Rights debate over whether states have an obligation to provide assistance to fulfill such right(s) to consider how such obligation is to be fulfilled in the specific context of the right to food.

The Convention's approach is clear from the outset: food assistance is aimed at the eradication of hunger and should be provided only "when it is the most effective and appropriate means of addressing the food or nutrition needs of the most vulnerable populations." Contrary to previous conventions, food assistance is no longer regarded as a temporary instrument. For instance, the Convention no longer foresees, as its ultimate aim, the end for the need of food aid itself as was the case under the 1995 and 1999 Conventions. Food assistance is instead regarded a long term development tool. Further, the Convention strives to ensure that food aid is detached from Parties' trade interests. Indeed many are the provisions that explicitly exhort Parties not to use food aid to promote their market development objectives (article 2(b)(iv)), or in a manner that causes commercial displacement (article 2(b)(iv)). Practices that are known to create trade distortion are explicitly forbidden (article 5.9 and article 2(b)(iv)) while those that favour local and regional development are encouraged (article 2(b)(iii)).

The Convention also goes a step further than any other conventions when defining Parties' obligations on the way aid should be donated and places greater emphasis than ever before on the adequacy of the assistance, including the need to devise food assistance policies in consultation with beneficiaries. ${ }^{42}$ Significantly, the Convention's primary article is no longer one that solely specifies which country donates what -indeed such article no longer exists, see infra- but is article 2 on the 'principles of food assistance,' that, with its 20 headings, sets

Maastricht Principles on Extraterritorial Obligations in the Area of Economic, Social and Cultural Rights: An Overview of Positive 'Obligations to Fulfil”, November 16, 2012 〈http://www.ejiltalk.org/author/msalomon/ >. The opposite view, held especially by developed states, sustain that development aid is not the consequence of an international obligation but the result of a discretionary moral commitment and as Cataldi says 'therefore that sense of obligation on the part of states (opinion juris) which along with the diuturnitas is considered the constituent element of an international custom, does not seem to exist' see G Cataldi and G. Serra, 'tied development aid: a study on some major legal issues' (2010) 10 Italian Yearbook of International Law 219 at p. 222

${ }^{39}$ Cataldi and Serra Ibid

${ }^{40}$ Art 2 on the 'principle of food assistance' calls on Parties to 'always adhere to these principles' -emphasis added. The broad application of this provision is also to be inferred by the fact that when the Convention intends to limit an obligation to the commitment under the Convention it specifically says so, see for example various paragraphs in art 5 where wording such as 'under the convention' 'in respect of the commitments' are explicitly used to indicate that a specific obligations is limited to the assistance donated to fulfil the minimum commitments.

${ }^{41}$ This means that the validity of the principles there endorsed can no longer be questioned, at least by Parties. For example by agreeing to the Convention the US has recognized that local and regional purchases are effective means of providing assistance. This is very important in the US context where the Congress' opposition to reform US food aid has focused on questioning the benefits of triangular and regional purchases (see infra).

${ }^{42}$ See art 2. 
the rules on the quomodo of food assistance (i.e. the ways in which assistance should be donated) and is the heart of the new Agreement. These latter obligations are central to the achievement of the Convention's new objectives to provide assistance which is adequate to meet beneficiaries' needs and that is safe, efficient, effective nutritious and based on needs (article 1). Such emphasis is also part of the Convention's new objective to 'seek to improve the effectiveness, efficiency and quality of food assistance' (preamble paragraph 2) indeed only by improving the rules on the way the assistance is donated can it be made more effective; it reflects the initial mandate of the IGC working group renegotiating the $\mathrm{FAC}^{43}$ and is in line with the international context of the many aid effectiveness initiatives that since 2002 have followed one another and within which the Convention is to be placed. ${ }^{44}$ In this respect, by being the first and only agreement to set the rules which implement the internationally agreed aid effectiveness targets and that incorporates well established principles of food aid effectiveness, the Convention not only places itself within the stream of those initiatives but takes the lead when it comes to setting standards for enhancing the effectiveness of food assistance. ${ }^{45}$

It is submitted that the Convention's new objectives breathe new life into the commitments endorsed by Parties and assign a new significance to the role the Convention could play in the eradication of hunger debate. It is in light of these new objectives that the Convention will need to be interpreted and its implementation by Parties assessed.

\section{B. New name, new ethos and new governance?}

The first change brought about by the new Convention lies in its title. After nearly 45 years the name of the Convention has been changed from the Food Aid Convention to the Food Assistance Convention (emphasis added). Problematically however, the term 'assistance' has not been defined and it has not been clarified whether and how it differs from the term 'aid' despite the latter being used in one instance in a distinctive manner from assistance, implying that the two terms are different. ${ }^{46}$

As noted by Clark and Clapp the new name 'reflects that the new treaty allows for more kinds of assistance (beyond just food and seeds) to be counted by donors as part of their commitments, ${ }^{\prime 47}$ mirroring also the fact that for more than a decade food aid 'has not been limited to the provision of food but has included the provision of cash (or a combination of

\footnotetext{
${ }^{43}$ The IGC mandate was to draft 'a new Convention committed to providing appropriate and effective food assistance' see FA Committee 103 session (n22)

44 The very preamble to the Convention places food aid within the global discourse on enhancing aid effectiveness. The 2005 Paris Declaration on aid effectiveness is expressly recalled at para 5, together with reference to the Rome Principles for Sustainable Global Food Security and the 2009 Declaration of the World Summit on Food Security.

${ }^{45}$ For example the principles in art 2 include providing assistance in such a way as to protect livelihood and local production, avoid dependency, involve beneficiaries in the assessment of their needs, purchase food locally or regionally whenever possible, provide untied cash-based food assistance etc. Such principles have been recognized by the international community (see for all the Paris Declaration on aid effectiveness) and are now for the first time incorporated into a legally binding agreement.

${ }^{46}$ Art 2(a)(vi) specifies that food aid (so not food assistance) is to be provided [always] in fully grant form whenever possible. A similar obligation is provided for food assistance in Art 5.7, but in this instance the obligation is limited to commitments under the Convention. Given that the broader obligation applies to aid only it is reasonable to assume that 'aid' is different from 'assistance'.

${ }^{47} \mathrm{~S}$ Clark and J Clapp, 'The 2012 Food Assistance Convention: Is a Promise Still a Promise?' 〈http://triplecrisis.com/the-2012-food-assistance-convention-is-a-promise-still-a-promise/〉
} 
both). ${ }^{48}$ Arguably, however, the new name does not just reflect the broader range of options available to donors to fulfil their commitments ${ }^{49}$ but it also underlines a new ethos governing the relationship between Parties to the Convention -donors of assistance- and beneficiaries characterised by mutual collaboration and participation in the design and implementation of food security and food assistance policies.

The term 'Assistance,' defined in the online Oxford Dictionary as 'the action of helping someone by sharing work', ${ }^{50}$ helps to emphasise the shift from the donor-centred approach of previous $\mathrm{FACs}^{51}$ to a new partnership between Parties to the Convention and beneficiaries of assistance. The new ethos also reflects the call for a strong donor-beneficiary relationship made by the many aid effectiveness initiatives which have followed one another in the past decade, ${ }^{52}$ it is in the context of those initiatives that the Convention's approach is to be placed (it is no coincidence that many of those initiatives are recalled in the preamble to the Convention). An array of provisions within the Convention helps operationalize this change: from the rules related to the ways in which the assistance should be provided to those specifically concerned with products and standards. For instance, from the very outset and with a view to enhancing aid effectiveness, Parties are encouraged to strengthen cooperation and coordination with beneficiaries (preamble, paragraph 2); beneficiaries are urged to develop and implement 'country-owned strategies that address the root causes of food insecurity'(preamble paragraph 5) and are recognised as having 'the primary role and responsibility for the organisation, coordination and implementation of food assistance operation $^{\prime 53}$ (emphasis added). Again in Art 2 Parties are asked to involve beneficiaries in the assessment of their needs and in the design, implementation, monitoring and evaluation of food assistance. ${ }^{54}$

Beneficiaries' role is further emphasised by the new rules on food standards and on adequate and eligible products. Article 2(c)(iii) by requiring donors to 'provide food assistance that meets applicable safety and quality standards,' and by eliminating previous reference to international standards, opens up the possibility that recipients' national food standards are taken into account when deciding what to donate as assistance. ${ }^{55}$ This, as further explained below, unlocks a whole new range of options in relation to the legality, quality and 'adequacy' of the assistance.

\footnotetext{
${ }^{48} \mathrm{lbid}$. Donors' commitments now include the use of cash and vouchers and other items (see infra).

${ }^{49}$ The fact that cash and vouchers could also be covered by the term 'aid' has never been doubted, besides art 4.3 and Rule 3 of the Rules of procedures and implementation which define what can be included as commitment could have alone sufficed to ensure broader range of options available to donors to fulfil their commitments.

50 (http://oxforddictionaries.com/definition/english/assistance)

${ }^{51}$ See in contrast art VIII para (g) of the 1999 FAC which only exhorts members to consult with each other, coordination and collaboration was there limited to 'between members'.

${ }^{52}$ The international community has responded to the criticism against aid via an array of initiatives aimed at enhancing aid success: four high level fora on aid effectiveness have followed one another since 2000, and various declarations and plan of actions have been endorsed by donor and recipient countries to make aid more effective. For example the Paris Declaration on Aid effectiveness recalled in the preamble to the Assistance Convention

53 Art 2 para (b)(viii)

${ }^{54}$ Art 2 para (c)(ii)

55 The 1999 FAC art 2(c)(iii) referred to 'international standards,' the Convention removes reference to international standards mentioning simply 'applicable safety and quality standards'. This indicates that now recipients' national standards can also be taken into account. See also art 4(3).
} 
The rules on the modalities of the assistance are also important in this context. For instance, donors are asked to reduce the provision of in-kind tied food aid that, amongst other problems, has also been associated with low levels of adherence to beneficiaries' food preferences. ${ }^{56}$

However, how far does the Convention go in redefining beneficiaries' role within the Convention? Does, for example, the renewed partnership transmute into a renewed system of food aid governance? Can beneficiaries become Parties to the Convention? Do they have a concrete chance to influence the adoption of multilateral food security policies? The following pages address these issues by looking at the Convention institutional settings and argue that although some of the new provisions could help fill the governance gap within the Convention problems still remain which risk compromising the Convention's credibility and legitimacy to influence the global food security discourse.

\section{Institutional settings:}

a) Accession to the Convention and Participation in the work of the Food Assistance Committee

The possibility to become a Party to the Convention is open to countries who were previously members of the FAC, to all other States and, for the first time, to Separate Customs territories. ${ }^{57}$ It remains unclear whether this possibility is now also open to beneficiary countries $^{58}$. An interpretation that supports beneficiaries' participation seems favoured both by the fact that, when setting the rules for accession, the Convention does not distinguish between states who provide assistance and states that receive it (the Convention simply refers to 'States'), and by the fact that explicit reference to countries' capacity to make minimum commitments (present instead in the $1999 \mathrm{FAC}^{59}$ ) has been removed from the Convention itself. ${ }^{60}$

\footnotetext{
${ }^{56}$ See below the extensive discussion on tied food aid.

${ }^{57}$ Art. 12 and 13. According to art 13(2). Custom territories can accede to the Convention only after being deemed eligible by a decision of the FA Committee. When considering an application for accession made by Custom Territories the Committee will take into account the minimum annual commitment that the applicant is prepared to make. When reading both the French and English versions of art 12 and 13 it remains unclear whether the FA Committee's decision -and the procedures for reaching such decision- is mandatory when both Custom Territories and other states who were not previously members of FAC make an application or just for the former. Rule 13, which provides details on how the Committee can reach its decision, is silent on this point. Besides Rule 13 contains a grave typological error in that it wrongly refers to art 13(1) instead of 13(2) [article 13(1) refers back to art 12, i.e. FAC members who can accede to the Convention at any time, Rules 13 should instead have referred to art 13(2) and should have clarified if the procedures on the FA Committee's decision on Parties accession applied to both states and custom territories].

${ }^{58}$ Some have argued that the Convention is not open to beneficiary states, see IFRC, 'IFRC calls on states to ratify the Food Assistance Convention' (IFRC, 17 February 2014) 〈http://ifrc.org/PageFiles/119268/IFRC\%20call\%20for\%20ratification\%20of\%20the\%20Food\%20Assistance\%20 Convention.pdf > in my view only vulnerable populations are precluded from accessing the Convention because, even though they can now be beneficiaries of assistance, they are not 'States' or 'other custom territories'.

${ }^{59}$ The 1999 FAC reference to minimum commitments was set in Art III (i) at 20000 tonnes (with the possibility to be reduced to 10000 tonnes over a period of 3 years under certain circumstances). This led to the assumption that countries unable to provide food aid could not accede to the FAC.

${ }^{60}$ Indirect reference to minimum commitments is present in Rule 13 of the Rules of Procedures and Implementations establishing that in considering an application for accession to the Convention under article
} 
Since beneficiaries' participation to the Convention is a radical departure from the past, clarification on this point would be beneficial. No beneficiary country is currently a Party to the Convention. The FA Committee will have a fundamental role to play in encouraging such participation. The first meetings of the Committee under the new Convention suggest that positive steps in this direction have been taken as two beneficiary countries, namely Cuba and Kenya, have for the first time participated as observers to the meetings of the FA Committee. Arguably only by institutionalising beneficiaries' presence within the Convention will they be able to influence multilateral food aid practices. Any other position would relegate partnership between Parties and beneficiaries to a bilateral affair with donors capable of influencing only individual aid projects at donors' discretion.

NGOs and International organisations continue to be precluded from becoming Parties to the Convention (because they are neither 'States' nor 'custom territories'). Yet these non-state actors play a prominent role in many developing and Least Developed countries, and generally on the global food security scene. For example in 2012 the WFP delivered over 50 per cent of all food aid donations to developing and LD countries. Excluding such major players of food assistance (and primary holders of food assistance knowledge) could weaken the Convention's impact on the global food security debate and its success in devising suitable food assistance strategies. In the past, this governance gap has been filled by inviting international organisations as observers to the meetings of the FA Committee. Participation however was limited to a few international organisations and to donors of aid (observers included 'new' donors such as Brazil and South Africa.)

The possibility of inviting non-parties to the FA Committee's meetings has now been formalised by article 9(4) which foresees the possibility that the committee may invite observers and relevant stakeholders who wish to discuss particular food assistance related matters...' (Emphasis added). This provision has been described as signalling 'a potential shift toward greater transparency and openness in the operation of the treaty. ${ }^{\prime 61}$

However, the process for inviting non-parties remains unclear as no information is provided on what type of criteria the Committee should follow to select or accept requests of participation by interested stakeholders. The Committee maintains full discretion on whether and when to invite non-parties. ${ }^{62} \mathrm{~A}$ broad range of stakeholders have been invited to the first three meetings of the FA Committee since the adoption of the Convention ${ }^{63}$ including NGOs

13 (1) of the Convention, the Committee is to take into account all relevant factors, in particular the minimum annual commitment that the applicant is prepared to make in accordance with article 5 (1) of the Convention' (emphasis added). It could be argued that because the minimum annual commitment is the only factor mentioned and because no explanation is given of what other 'relevant factors' could be taken into account, the 'minimum annual commitment' element acquires special importance, to the extent that it could be questioned whether the Committee could grant accession to States that are unable to make (appropriate) minimum commitment. However another aspect of this provision is unclear, namely whether it at all applies to States or to custom territories only. The language (in both the French and English official versions of the Convention) suggests that it applies to the latter only. Furthermore, such indirect reference to minimum commitment cannot be compared to previous reference to minimum commitments under the 1999 FAC as in that instance specific quantities of commitments were set and hence would be insufficient to exclude beneficiaries States.

${ }^{61}$ Clapp and Clark (n 47)

This is clear from the adoption of the wording 'the committee may invite'. It seems that some sessions of the meetings, i.e. the so-called 'closed meetings' continue to be reserved to Parties only.

${ }^{63}$ International organisations and other donors were also invited. The second meeting on 12 November 2013 saw participation as observers by representatives from Brazil, Slovenia, Spain, the World Food Programme, and the Canadian Foodgrains Bank (the latter a NGO). This meeting was preceded on 11 November by a seminar on nutritional interventions that involved a wide audience, for example a representative from Save the Children 
and beneficiaries (together with international organisations and other donors). It is hoped that this trend towards broader participation will continue in future. Participation by beneficiaries and NGOs could have a positive impact on the discussions that will be held at the meetings -allowing for example consideration of interests that are not exclusively driven by donors' interests and accounting for other forms of governance closer to people and society. ${ }^{64}$ However, the powers that invited stakeholders retain remains limited. ${ }^{65}$ For example, only Parties to the Convention have equal right to vote and veto decisions being taken by the Committee ${ }^{66}$ and invited observers cannot oppose the adoption of a decision by the Committee. Similarly, observers cannot raise claims for failure to implement the Convention's commitments ${ }^{67}$ and do not have access to Parties' annual reports. ${ }^{68}$ Arguably, only when all the actors that are involved in deploying assistance have an equal role in the workings of the FA Committee, being fully integrated in the decision-making and informationsharing processes which take place at the Convention's institutional level, can a new system of food aid governance be established. One that is fully in line with the Convention's shift from food aid as surplus disposal (and hence as donors' only business) to food assistance as a long term tool to face food Security.

\section{Coverage: the quantum and quomodo of Parties' commitments}

\section{Parties' quantum obligations: the 'Minimum annual commitment'}

a) A flexible approach to Parties' annual commitment

\footnotetext{
was also invited, yet Save the Children was not present at the formal meeting the following day. The seminar was 'aimed at exchanging information on activities and best practice, as well as improving the common understanding on global needs and gaps. See FA Committee, Press release, 12 November 2013, 〈http://foodassistanceconvention.org/en/press/press.aspx). A report of the session is available at 〈http://foodassistanceconvention.org/downloads/sumrec/fac1 sr.pdf) The third meeting was attended by all signatories to the Convention and former members of the Food Aid Committee, the government of Brazil was also present as an observer together with two beneficiaries, namely Cuba and Kenya, and a representative from TAFAD (representing a group of NGOs).

${ }^{64}$ For example remarkable is the role played by TAFAD (Trans-Atlantic Food Assistance Dialogue, an association of NGOs) during the process of renegotiating the Convention in terms of gearing towards food security the discussions held during the negotiations for the new Convention and lobbing for greater transparency and better use of aid resources. TAFAD is also to be praised for bringing discussions regarding the FAC to the public attention. It is therefore not surprising that representatives from TAFAD have been invited to the meetings of the FA Committee since the adoption of the new Convention.

${ }^{65}$ Rule $12(d)$ of the Rules of procedures and implementation states that 'proceedings of formal sessions and informal meetings are to remain confidential.' This provision is laid down in the context of determining the rules for participation of interested stakeholders in the works of the committee so it is directly relevant to proceedings of meetings where those stakeholders are also present. This will also limit the possibility to monitor the role played in the meetings by non-Parties (and more generally knowing whether the decisions of the Committee are inclusive of their interests)

${ }^{66}$ According to art 7(4), the FA Committee adopts decisions by consensus, i.e. any Party to the Convention can oppose a decision by the Committee.

${ }^{67}$ See art 11 only Parties have the right to pursue breaches of the Convention's obligations and to uphold its implementation

${ }^{68}$ See further section 4.
} 
In order to meet the objectives of the Convention each Party agrees to make annual commitments of food assistance, known as 'minimum annual commitment' (article 5(1)). Donors can of course donate more than their minimum commitment if they want to.

Individual (for each member) and collective (together for all members) levels of commitments used to be inserted in the FACs' text. Members were bound to those specific commitments (without the possibility to modify them) for the whole life of the Convention and could be modified only once a new convention was adopted. For example, with the 1986 and 1995 FACs, members agreed to secure collectively at least 10 million tons of food annually. ${ }^{69}$ This was reduced by the 1999 FAC to approximately 4.9 million metric tons (mmt) of food. ${ }^{70}$ Individual commitments differed significantly for each member. For instance, in 1999 the US committed to donate 2,500,000 tonnes of wheat equivalent while Argentina committed 35,000, the EU and all its Member States 1,320,000 tons and Euro 130 million (for a total indicative value of Euro 422 million $^{71}$ )

The Assistance Convention brings in significant changes in this area. Parties' commitments are no longer specified in the text of the Convention and no total collective level of assistance has been agreed. Each Party instead is to notify the Secretariat of its annual commitment by 15 of December each year. ${ }^{72}$ The level of commitment can be different each year (hence, Parties' commitments could be decreased or increased from year to year.) The (updated) level of minimum annual commitment for each Party will be communicated to all the Parties to the Convention by the first of January of each year by the Secretariat.

A flexible approach to commitment was probably necessary and instrumental given (and to ensure) the a libitum nature of the Convention and to avoid the (painful) process of renegotiating the Convention every few years. ${ }^{73}$ However, in an era where the call for certainty and predictability of donors' donations is strong and food price fluctuations can steer hunger and starvation across the globe, the Convention's flexible approach on Parties' commitments is, at the very least, surprising if not undesirable. This is especially so since the possibility to change the level of commitments each year risks institutionalising the countercyclical nature of food aid, i.e. if harvests are low in a given year (for example in July) Parties can (now legitimately) reduce their commitments (in December) for the following year. ${ }^{74} \mathrm{~A}$ cause of further criticism is also the fact that no food security assessment is linked to the level of commitments made (both for the initial commitment and for subsequent ones)

\footnotetext{
69 Target recommended by the 1974 World Food Conference.

${ }^{70}$ Art III of the 1999 FAC laid down the specific commitment for each member. The USA pledged to provide 2.5 mmt equal to $51 \%$ of the total commitment, see C Hanrahan and C Canada International Food Aid: U.S. and Other Donor (, Congressional Research Service, 2011). The 10000 tons commitment remained as a general goal in the preamble to the 1999 FAC. See J Hoddinott, M Cohen and C Barrett, 'Renegotiating the Food Aid Convention: Background, Context, and Issues' (2008) 14 Global Governance 283.

${ }^{71}$ For the first time in 1999 the EU commitment was expressed through a "a combination of value and quantities" (art III (E) of the 1999 FAC.)

72 (Art 5.(4) and 5.(5)) initial annual commitment are to be notified within three months of a Parties' accession to the Convention

${ }^{73}$ Renegotiating the Convention had been a long a painful process and one which Parties wanted to avoid having to repeat on a regular basis. At the same time the absence of a termination date meant that Parties required the option to be able to to modify their financial commitments over time.

${ }^{74}$ The countercyclical nature of food aid donations have long been exposed by critics (i.e. food aid is least available when prices are high and food is needed the most, abundant when prices are low. See J Hoddinott et all (n 14). The Convention, by allowing parties to modify their commitments each year, institutionalises and legalise the countercyclical nature of food aid and although this defeats the spirit of the Convention, it is still permissible within the rules.
} 
raising the suspicious that the only rational for the Convention's flexible approach to commitments is to allow Parties to take into account their own financial situation rather than the world's food insecurity status.

Another cause of concern is the absence of specific mechanisms preventing Parties from unreasonably reducing their commitments and guaranteeing that adequate levels of assistance continue to be provided. For example, Parties do not have to justify the changes made to commitments nor are they required to monitor the food security impact of those changes. $^{75}$

This author believes that Parties should have been invited to express their commitments on a multiannual basis (for example on a five year cycle ${ }^{76}$ ), as this would ensure predictability of resources while guaranteeing flexibility and avoiding speculation on the basis of price fluctuations. Parties should also be required to disclose the reasons for introducing any change to the level of commitments and, if changes are made, should undertake food security analysis of their impact. This would ensure accountability and allow the adoption of measures limiting negative food security effects (for example other Parties could be lobbied to fill the commitments gap left by the Party who has made the reduction).

In the absence of any other mechanism, peer and public pressure alone are left to deter Parties from reducing their commitments. However their success is linked to the quality of the information available and to the widespread availability of that information. It is hoped that the FA Committee will facilitate the sharing of information amongst Parties and to the public, ensuring Parties release intelligible data on the level of aid donated each year and clearly indicating if commitments have been reduced. It is hoped that such information will also be easily available to the public.

A final point to consider is whether the absence of Parties' specific commitments in the Convention's text affects the nature of the obligations endorsed. The FAC(s) were praised for being the only international treaties to impose a legal obligation on donors to provide specific quantities of food aid donations, ${ }^{77}$ does the fact that the Convention no longer specifies the amount of food assistance that Parties will donate weaken the strength of the obligations endorsed? A negative answer to this question seems appropriate given that, even though Parties' commitments are not expressed in the Convention's text, each Party is required to communicate the Secretariat, ahead of the year for which the commitment is due, the specific commitment endorsed, thus entering a legal obligation to provide the stated assistance for each year.

b) Minimum value, minimum quantity or both

When the FAC was first adopted Members' minimum annual commitments were expressed exclusively in tonnages of wheat equivalent. ${ }^{78}$ The $1999 \mathrm{FAC}$ introduced for the first time the possibility to express commitments in value also. In this latter instance however members were also required to specify 'a guaranteed annual tonnage, ${ }^{79}$ ' to avoid that FAC

\footnotetext{
75 Some NGOs (TAFAD and the Food grains Bank) have stressed the weakness of this aspect of the Convention and are lobbing for greater predictability and transparency. See http://www.foodgrainsbank.ca/news

${ }^{76}$ Indeed, predicting price fluctuations on a five-year cycle is more difficult than from year to year.

${ }^{77}$ Clapp (n 5).

${ }^{78}$ Fairly soon members' donations included cash and vouchers but members' commitments continued to be expressed in wheat equivalents

${ }^{79}$ see article III (b) of the 1999 FAC
} 
commitments were conditioned by food price fluctuation, i.e. no matter how much the price of food increased, members were still obliged to guarantee their minimum annual food tonnage.

The Assistance Convention has introduced a major novelty: parties can now express their commitments in terms of minimum value, in tons of wheat equivalent or both ${ }^{80}$, without having to specify a guaranteed annual tonnage (article 5(2)). ${ }^{81}$ Food aid experts have voiced major concerns on the possible negative impact that this provision could have on food insecurity. ${ }^{82}$ Indeed, abolishing the requirement to guarantee minimum food tonnages might lead to insufficient food quantities when food prices are high as the purchasing power of cash donations diminishes and less quantities of food can be purchased. Yet Parties still fulfil their Convention's commitments. This is an offbeat measure that goes against the primary aim of the Convention, namely food security. Rigorous monitoring will be necessary on the impact that this provision will have in terms of food security implications for beneficiary countries to ensure that the Convention's capacity to act as a guarantee for food security is not compromised. Worryingly the Convention does not foresee any mechanism to this effect.

It seems that one of the rationales behind the adoption of this provision was the desire of most of the government representatives negotiating the Convention to avoid bureaucratic impasses like those created during the 2008 "Food Prices Crisis" when aid officials had to repeatedly apply for new budget allocations to cover the costs of increased food prices in order to fulfil their FAC obligations (at the time expressed in quantities of wheat equivalent). This was, for example, a major problem for the European Commission that under the 1999 FAC had committed to provide 500,000 tons per year, yet because of the increase in food prices the original budget allocated for food aid purchases and transferred from DG Development to ECHO was insufficient to cover the actual costs of the original FAC tons commitments (ECHO food aid service had to repeatedly apply for additional funds to meet what was for them the same obligation.) This situation had caused frustration at both the administrative and political levels and has contributed to the adoption of the unfortunate decision to opt for value commitments only without the obligation to express a quantity equivalent. Hence the incapacity to plan, to monitor food prices, the rigid institutional bureaucracies to which donors are bound and the incapacity of the international system to prevent food price speculations have prevailed compromising the effectiveness of the Convention to act as a guarantee for food security.

\section{c) Activities and products}

Parties can fulfil their commitments via donating eligible products, cash and vouchers, and via nutritional interventions (classified as eligible activities by article 4.4 and Rule 1 of the rules of procedure and implementation). The list of activities is broad yet it does not

\footnotetext{
80 Parties can choose the currency through which to express their value commitments. Quantity commitments can be expressed in tons of wheat equivalent or in other units of measure as per the Rules of Procedures and Implementation (article 5(3))

${ }^{81}$ Since not all Parties have yet disclosed their minimum annual commitment, it is not possible to comment on whether Parties will donate more or less than under previous conventions. Comparisons are complicated further by the fact that it is difficult to ascertain how donors' value commitments will convert in quantities of food assistance (i.e. how much food will be possible to purchase with the cash donated) because this will depend each year on food prices and on the purchasing power of the currency chosen by donors.

${ }^{82}$ See especially the comments and press releases published by TAFAD, The Trans-Atlantic Food Assistance Dialogue ( http://www.fixturesdesign.com/tafad/about/) and J Hoddinott, M Cohen, and C Barrett (n 14).
} 
incorporate options such as payment for the costs of insurance schemes which, as suggested by the former Rapporteur on the Right to food, Olivier De Schutter, could provide a new and better form of guarantee for food security. ${ }^{83}$

Donating cash is generally regarded very favourably by food security experts. This is because cash donations can best respond to needs assessment and to beneficiaries' food preferences (provided no conditions are attached on where the cash is being spent, see infra). The EU, Canada, and Japan provide a mix of commodities and cash, while other donors, the United States for example, continue to donate mainly food aid in-kind.

The list of eligible products is vast and much expanded compared to any other previous conventions. In the seventies' and the eighties' FACs the list of eligible products comprised cereals only. The list was expanded for the first time in 1995 when the new FAC introduced non-cereals commodities (namely pulses), included because of pressure by the Australian and the Canadian Governments who had pulse surpluses. The 1999 Convention further expanded the list to other non-cereal commodities such as dairy and seeds products, ${ }^{84}$ reflecting both the broader range of (surplus) stocks available to donors and the complexity of beneficiaries' nutritional needs. The Convention has now included supplementary and therapeutic food, ready to use food and tools and other equipment for food preparation. ${ }^{85}$

Eligible products have to comply with relevant national policies and legislation of the country of operation (article 4.3) and with applicable food safety and quality standards (article 2 (c)). The reference to national policy and legislation of the country of operation is an important innovation introduced by the Convention (previous conventions referred to international standards only) which contributes to strengthen the role of beneficiaries in donors' food assistance activities and is very important when assessing the 'adequacy' of the food donated (see infra). Beneficiaries concerned that donations do not conform to their cultural, religious and social habits -and the negative effects that such donations could have (i.e. social discontent, incapacity to fully utilise the food donated, permanent dietary change followed by dependency due to incapacity to produce similar food, etc) - could enact legislation that specifically safeguards those habits. Parties to the Conventions that breach such legislation would now also breach the international obligations endorsed under the Convention. Article 4.3 is important in the context of current debate on Genetically Modified food (GM Food). For example, donors who in the past have tried to overcome recipients' ban to GM food aid would now be in breach of the Convention if such ban is part of beneficiaries' national policies and legislation.

Finally, Parties' contribution can be provided bilaterally, through international organisations and NGOs or through other food assistance partners (which could arguably include also private sector parties) but they cannot be donated through other Parties (article 5.12). The 1999 FAC encouraged members to provide aid through multilateral channels, and through the WFP in particular (see article XI (b) of 1999 FAC). The Assistance Convention contains no such provision, probably because Parties already channel most of their food assistance via the WFP (testament to the important role played by this international organisation).

\footnotetext{
${ }^{83}$ See UNCHR 'The role of development cooperation and food aid in realising the right to adequate food: moving from charity to obligation, Report by Special Rapporteur O De Schutter' (March 2009) UN Doc A/HRC/10/005. ${ }^{84}$ In this respect Clay had argued that products under the 1999 FAC covered virtually 'the entire range of commodities and processed foods likely to be provided as humanitarian relief or in nutritional programmes $\mathrm{E}$ Clay, 'Future Food Aid or Food Assistance Convention?' (ODI Background Paper on Food Aid No. 6, July 2010).

${ }^{85}$ Rule 3 of the Rules of Procedure and implementation.
} 


\section{Parties' quomodo obligations: adequate and effective food assistance}

The Assistance Convention places great emphasis on what principles Parties should follow when providing assistance and how assistance should be provided and delivered. These quomodo obligations complement and complete the quantitative commitments and ensure that Parties adhere to the primary objective of the Convention to provide adequate, effective and culturally acceptable food. The foundations of these obligations are mainly laid down in article 2 which is of broad application, i.e. its scope extends beyond the boundaries of the minimum commitments, and hence Parties will have to ensure that they respect these principles whenever providing food assistance as the article calls on Parties to 'always adhere to these principles.' Article 2 is then strengthened and complemented by other more detailed provisions; these sometimes exclusively apply to assistance provided under the Convention. ${ }^{86}$

a) Adequacy of assistance: a holistic approach to 'adequacy'?

The concept of adequate food assistance has been developed by international human rights instruments that explicitly endorse the right to adequate food and to be free from hunger. ${ }^{87}$ 'Adequacy' has also been promoted by the former UN Special Rapporteur on the right to food, Professor Olivier De Schutter, who took a holistic approach to this concept defining it as assistance which 'must satisfy dietary needs, taking into account the individual's age, living conditions, health, occupation [which is]...safe for human consumption and free from adverse substances, such as contaminants from industrial or agricultural processes, including residues from pesticides, hormones or veterinary drugs. Adequate food should also be culturally acceptable. For example, aid containing food that is a religious or cultural taboo for the recipients or inconsistent with their eating habits would not be socially acceptable. ${ }^{88}$ ' The Convention fully endorses this approach via a series of provisions which exhort Parties to uphold, when donating assistance, the 'dignity of beneficiary country', to respect their 'cultural and local dietary habits' and to provide assistance 'based on needs and shared principles' ${ }^{89}$

Providing 'adequate, safe and nutritious food' is one of the major objectives of the Convention (article 1(a)). This objective is further elaborated in article 2 via a series of provisions setting the principles to which Parties should always conform when granting food assistance. ${ }^{90}$ Thus, Parties are required to target food assistance according to beneficiaries' nutritional needs and to provide assistance in such a way that avoids dependency and

\footnotetext{
${ }^{86}$ I will specify below when a commitment is of general application and when instead it is limited to the annual commitment 'under the convention'.

${ }^{87}$ For example art 11.1 of the International Covenant on Economic, Social and Cultural Rights (ICESCR) The content of the right to adequate food has been further clarified by the Committee on Economic, Social and Cultural Rights (CESCR) in General Comment No 12 which states: 'the right to adequate food is indivisibly linked to the inherent dignity of the human person and is indispensable for the fulfilment of other human rights enshrined in the International Bill of Human Rights'. See Committee on Economic, Social and Cultural Rights (CESCR), Right to Adequate Food (Art 11)-General Comment 12 UN Doc E/C.12/1999/5 (1999).

${ }^{88} \mathrm{See}$ ( http://www.srfood.org/index.php/en/right-to-food)

${ }^{89}$ Articles 2(d), 2(c)(iii) and 1 (b) respectively.

${ }^{90}$ See for example articles 2(a)(i), 2(a)(ii) 2(a)(iii).
} 
protects livelihoods. Parties are also asked to conduct careful assessments of beneficiaries' markets and food preferences when devising their food assistance policies -especially when deciding whether to donate cash or food and what type of products to donate. As seen above, close collaboration between Parties and beneficiaries and between aid agencies is regarded paramount in the Convention and beneficiaries are explicitly exhorted to play a part in the design of food security and food assistance policies (see above section 2.A and 2.C). Beneficiaries' direct participation in the 'design' of food assistance policies is key to ensure these are 'adequate' to fulfil their needs. Important in this context are also the new rules on standards analysed above in that Parties are now required to consider beneficiaries' food policies and standards and are prevented from making donations that contrast with them.

b) Mode of delivery: In grant form, untied and purchased in local or regional markets

The Assistance Convention, as previous conventions before it, encourages Parties to provide assistance in grant form and specifies that no less than $80 \%$ of the contribution made to fulfil annual commitment should be in fully grant form (article 5.7).$^{91}$ The 1999 FAC also established that, with respect to food aid counted against a members' commitment, all food aid donated to LDCs had to be provided as grants surprisingly such requirement is not endorsed by the new Convention.

Interestingly, in article 2(a)(vi) the Convention specifies that food aid (for the first time distinguished from food assistance) is to be provided in fully grant form 'whenever possible.' As the principles in article 2 are 'always to be applied by Parties' (Art 2, first paragraph) the obligation to provide food aid as grants extends to donations beyond the minimum commitments. It remains unclear however how aid is to be differentiated from assistance.

The Convention, reiterating principles already advocated by previous FACs, commits Parties not to use food assistance provided under the Convention as a means for increasing exports and distort normal patterns of international trade. ${ }^{92}$ It then goes beyond any convention before, by requiring, in article 2, Parties to (always) provide food assistance in a way that does not adversely affect local production, marketing structure and commercial trade or the price of essential goods for vulnerable populations. ${ }^{93}$

The Convention, as the 1999 FAC before, also takes a formal stance against tied aid, i.e. aid provided on condition that the food for the aid-financed project are purchased from the donor country only. Article 5.9 of the Convention commits Parties to provide assistance which is not tied 'directly or indirectly, formally or informally, explicitly or implicitly to commercial exports of agricultural products or other goods and services to recipient countries' (this article reproduces, with the same exact words, article IX (e)(i) of the 1999 FAC).

For the first time, the Convention extends the commitment to untie assistance to cash donations, Parties are now encouraged to increasingly provide untied cash-based food assistance whenever possible and based on needs' (article 2(b)(iv)). It is worth noting that

\footnotetext{
${ }^{91}$ Development assistance can be donated as grant or concessional sales (also known as soft loans), while grants do not need to be repaid concessional sales will need to be paid back by beneficiaries albeit on terms more convenient than market prices but which nonetheless involve expenditure for the recipient country.

92 Art 5.8 .

${ }^{93}$ Article 2 (a)(v). This principle always applies whenever Parties donate food assistance.
} 
both provisions seem applicable to all food assistance granted by Parties and not just to assistance provided to meet minimum annual commitments. ${ }^{94}$ This is not surprising given that the benefits of aid untying are now widely endorsed by the international community; for example, increasing the level of aid which is untied figures within the targets of the 2005 Paris Declaration on enhancing aid effectiveness.

A look at the negative effects of tied food aid helps understanding why the Convention has extended the commitment to untie aid to all assistance provided, including cash. Tied food aid is $30-50 \%$ more expensive than food purchased through commercial transactions. ${ }^{95}$ Tying often distorts the nature of the aid as the food received by beneficiaries is defined by donor's production (and surpluses) rather than beneficiaries' needs. Hence, donations risk being inadequate or culturally and socially unacceptable. Tying food aid is also associated with extensive delays in the delivery of the food, delays which can reach up to 62 per cent lost in timeliness when compared to local purchased. ${ }^{96}$

Despite its negative effects, a staggering $90 \%$ of food aid continues to be tied. ${ }^{97}$ The US is the main supplier of in-kind tied food aid, accounting for 89 per cent of all the direct transfers. ${ }^{98}$ The intricate links existing between food aid and trade (including the desire of some countries to offset direct agricultural subsidies granted by other parties ${ }^{99}$ ) and the political barriers encountered at the national level by some Parties, make untying food assistance a very contentious issue. Indeed, potent lobbies who gain from the assistance being tied exercise enormous pressure on governments and parliaments in donor countries to continue to tie aid. ${ }^{100}$ National and international proposals to untie food aid have encountered great opposition in some countries -the US case is emblematic where presidential initiatives to untie food aid have consistently been rejected by Congress. ${ }^{101} \mathrm{~A}$

\footnotetext{
${ }^{94}$ Indeed art 5.9 is not limited as instead other obligations in art 5 to minimum commitment only (compare for example art 5.9 with art. 5.7)

${ }^{95} \mathrm{~A}$ study by Clay shows that 'the actual cost of tied direct food aid transfers was, on average, approximately $50 \%$ more than local food purchases and 33\% more costly than procurement of food in third countries' See E Clay, The Development Effectiveness of Food Aid: Does Tying Matter? (OECD, 2005). P Harvey et all 'food aid and food assistance in emergency and transitional context: a review of current thinking' (Humanitarian Policy Group, 2010) ( http://www.odi.org/sites/odi.org.uk/files/odi-assets/publications-opinion-files/6038.pdf).

${ }^{96}$ On the increased timeliness of tied direct transfers see E Lentz, S Passarelli and C Barrett, The Timeliness and Cost-Effectiveness of the Local and Regional Procurement of Food Aid (Cornell University, 2012) http://www.dyson.cornell.edu/faculty_sites/cbb2/Papers/LRP\%20Ch\%202\%20Lentz\%20et\%20al.pdf accessed 1 September 2012. The US Government Accountability Office also found that food from the US is considerably slower than food purchased locally or regionally, and required 147 days on average to reach ten selected African countries, whereas locally purchased food was available in 35 days, and food procured in neighbouring countries in 41 days.' See USGAO, 'International food assistance: Key issues for congressional oversight' (United States Government Accountability Office, 2009) ( http://www.gao.gov/assets/130/122649.html〉

${ }^{97}$ Clay (n 95).

${ }^{98}$ Other donors also use tied food aid, for example Japan and Canada tie 45 per cent and 44 per cent of their food aid respectively. Others such the EU, make more use of triangular transactions, Clay ibid

${ }^{99}$ During the negotiations for reforming the WTO agreement on agriculture the US has explicitly linked negotiations to untie food aid to the abolition of direct subsidies by other WTO members.

100 Lobbies include agribusiness and shipping corporations, who produce and transport the food, and some NGOs (those who sell the food in beneficiaries' markets to finance their activities).

101 During the Bush administration, various attempts were made to change PL 480 and allow 25 per cent of food aid allocations to be purchased in developing countries through local and triangular purchases. These, however, were not endorsed by the US Congress that in 2005, 2006, and 2007 repeatedly rejected them. See, C Dugger, 'Poverty Memo: African Food for Africa's Starving Is Road blocked in Congress' New York Times, 12 October 2005, cited in Hoddinott, M Cohen, and C Barrett (n 13). A much more modest reform was instead implemented through the setting up of ad hoc programmes. A pilot LRP programme was established by the 2008 Farm Bill,
} 
strong international commitment to untie aid could be used by governments to overcome political pressure at the national level to tie aid. It is doubtful, however, whether the Convention could be able to perform this role. As for the 1999 FAC, many are the problems that persist within the Convention hindering the efficacy of the commitment to untie aid.

The wording used by the Convention remains weak. For example the commitment to untie cash donations is written in terms of best efforts endeavours and could easily be circumvented by parties. In article 2(b)(iv) Parties commit to 'increasingly provide untied cashbased food assistance, whenever possible and based on needs'. This is not an outright ban to tie cash donations, but rather an endeavor to 'increasingly' provide more untied cash assistance 'whenever possible and based on needs'. Many questions could be raised; for example, what 'needs' will be taken into account? And whose needs? Is it the needs of the population to be helped by the aid, i.e. the starving people, or the need of the local/regional market of the recipient country where the (tied) aid will be donated? Or simply the general 'need' to make aid effective?

Furthermore, it is arguable that a general commitment to untie aid, even if expressed in clear and enforceable terms, cannot alone suffice to prevent Parties from concealing discriminatory practices when procuring food. The commitment to ban tied aid can be made effective only by enhancing the transparency of the procurement process and putting national and international suppliers on equal footing, facilitating competition. ${ }^{102}$ This is, however, not to say that detailed rules on procuring food aid should be introduced but simple transparency mechanisms aimed at preventing Parties from concealing discriminatory practices could ensure the effectiveness of the untied provisions.

In order to understand how the agreement could be improved a comparison could be made with the OECD/DAC Recommendation on untying aid to LDCs and HIPCs, a 'gentlemen agreement' in the form of a recommendation was adopted in 2002 by OECD/DAC members (here and after the Recommendation), and so far this has been the most successful international initiative to untie aid, but which unfortunately exempts food aid from its coverage (paragraph 8(iii)). The Recommendation's strength lies in the fact that, together with a clear commitment to untie aid, it provides provisions that enhance transparency when purchasing food. For example, the Recommendation sets rules on the notification of tender awards and advertising of tender opportunities and it provides for the establishment of a website where untied aid offers are advertised, namely the untied bulletin board. The bulleting is freely accessible online. The transparency provisions are further complemented by the strong monitoring role assigned to the OECD/DAC Committee. A report is published each year on the state of implementation of the Recommendation, which contains various data and information on contracts notifications and tenders opportunities (for example, the number of aid offers advertised and notified to the DAC, the nationality of contractors awarded the tenders). The report is also available to the public. Publication of such information ensures accountability and encourages peer and public pressure. These few yet extremely effective provisions have ensured that over the years aid covered by the

\footnotetext{
Section 3206 (PL 110-246) which provided the US Department of Agriculture (USDA) with US 60 million dollars over four years (financial year 2009-financial year 2012) for LRP.

${ }^{102}$ Provisions to ensure transparency and fair participation of foreign suppliers in the procurement process include: wide publication of procurement notices and opportunities, adequate time limits to ensure sufficient time is allowed between publication of the notice and deadline for participating to the tender, award notifications. The literature on this topic is vast. See, for all S Arrowsmith, J Linarelli and S Wallace, Regulating Public Procurement (Kluwer Law International, 2000).
} 
Recommendation has been de jure and the facto untied. The Convention, in contrast, does not foresee similar obligations and remains very weak when confronted with ensuring that Parties untie aid de jure and de facto.. For example, it is unclear whether Parties are required to disclose the tied/untied status of their commitment in the annual report and whether this info will be circulated to the public. Mechanisms similar to those used by the Recommendation could be easily put in place under the Convention. For example, the Convention could use its newly established website to advertise Parties' procurement opportunities, the availability of such information could allow better monitoring and peer review of the fulfilment of the Convention's commitment not to tie aid. Enhanced transparency could incite peer and public pressure and could be a first step towards encouraging compliance. ${ }^{103}$

On a positive note, and linked to the quest to untie food aid, the Assistance Convention reinforces previous provisions in the 1999 FAC on local and regional procurement. Article 2(b)(iii) on Principles of Food Assistance exhorts Parties to the Convention to 'purchase food and other components of food assistance locally or regionally whenever possible and appropriate.' Although the commitment to purchase locally or regionally is expressed in terms of best effort endeavors, the preference for local and regional procurement is clearly manifested. This is apparent when comparing this provision to article XII of 1999 FAC on 'Local Purchases and Triangular Transactions ${ }^{104}$ ', which simply required members to 'give consideration' to purchase through local or triangular transaction. The Convention instead exhorts Parties to do so and clearly acknowledges that local and regional procurement are the best means for purchasing food aid. The EU and the UN make extensive use of local and triangular transactions and made the largest contribution of local and triangular purchases in the past five years.

\section{c) Other commitments: towards banning Monetisation}

Food aid donations are sometimes subjected to the process of monetisation, ${ }^{105}$ i.e. the food, which is provided in-kind from the donor's market, is sold on the beneficiary market and turned into cash by the beneficiary government, ${ }^{106}$ by NGOs, or by private voluntary organisations (PVOs). The cash is then used to finance other development projects or NGOs'

\footnotetext{
103 Other examples could be made, such as the Convention could have required Parties to provide ex ante and ex post information on the procurement opportunities issued each year, together with information on contract awards; the Convention's secretariat could perform the monitoring role undertaken by the DAC in respect of the OECD Recommendation.

${ }^{104}$ Art XII of the 1999 FAC stated: '(a) In order to promote local agricultural development, strengthen regional and local markets and enhance the longer-term food security of recipient countries, members shall give consideration to using or directing their cash contributions for the purchase of food: (i) for supply to the recipient country from other developing countries ('triangular transactions'); or, (ii) in one part of a developing country for supply to a deficit area in that country ('local purchases'). (...)'

105 The process of monetization is involved when aid is granted as programme food aid. The WFP defines it as 'food aid provided on a government-to-government basis. It is not targeted at specific beneficiary groups. It is sold on the open market and can be provided either as a grant or as a loan'. WFP, Food aid information system, www.wfp.org

${ }^{106}$ Donors and beneficiaries often reach an agreement on how the money generated by the food aid sold should be used.
} 
activities in the targeted beneficiary country. In 2006 , NGOs sold $30 \%$ of all the food aid they handled on the open market in recipient countries. ${ }^{107}$

The process of monetization started originally as 'partial monetization,' developed in order to generate funds to complete the implementation (including internal transport) of a food aid operation. However 'partial monetization' was then extended to the so-called practice of 'full monetisation' whereby some donors (the US for example via its development aid agency, USAID under Title II of PL 480) provide NGOs with commodities available on the donor's market (surpluses) for them to sell on the market of the recipient country.

The process of monetisation has been highly criticised. Experts have proved that the monetization of food aid has disastrous consequences on the local market where it is sold since it displaces local production, driving local farmers out of business.

In line with recent findings on the negative effects of food aid monetization, the Convention requires Parties to limit the use of this practice to cases 'where there is an identified need to do so, and to improve the food security of vulnerable populations'. Moreover the Convention requires food aid monetization to be based on 'transparent and objective market analysis' and to 'avoid commercial displacement' (article 2(b)(5). However, this provision still fails to convince. For example, nothing is said concerning who should conduct the market analysis -should it be conducted by a third independent body or by the same organisation that will benefit from the monetisation? If the market analysis is conducted by the same NGO that benefits from the monetisation then there is a risk of bias. In this author's view, the Convention should have inserted an express requirement to rely on market analysis conducted by external (third) parties. The use of in-house analysis should be permitted only where no external market analysis is available. The WFP, for example, conducts numerous market analyses all over the world, reference to the WFP analysis could be an easy and fast way to ensure that monetization is used only where no adverse effect is created in the local market.

d) Corollary obligations: reducing associated costs

Article 2(b)(i) of the Assistance Convention requires Parties to 'minimise associated costs as much as possible' in order to 'increase the amount available to spend on food and to promote efficiency'. Associated costs are those connected to activities necessary to provide and deliver the assistance, for example transportation, procurement, storage. ${ }^{108}$ These costs can be very high, especially when donors attach conditions to these activities that make them more burdensome and expensive, for example when donors require that the food donated is shipped by nationally-registered vessels. ${ }^{109}$ This is, for example, the case for most US food aid. ${ }^{110}$

\footnotetext{
${ }^{107} \mathrm{FAO}$, Responding to the food crisis: synthesis of medium-term measures proposed in inter-agency assessments (Rome, FAO, 2009) available at: www.fao.org/fileadmin/user_upload/ISFP/SR_Web.pdf accessed 1 September 2012.

108 Rule 2 of Rules of procedures

${ }^{109}$ See Lentz (n 96)

${ }^{110}$ US legislation (PL 480) requires that $75 \%$ of USAID and 50\% of USDA managed food aid be transported in

"flag-carrying" vessels registered in the US. Harvey et al (n 95). such conditions are also cause of further inefficiencies for example donors subject to tied transportation requirements cannot make use of more efficient means of purchase, such as purchasing food on the local and regional market. As USGAO noted, 'as long as US law requires 75 per cent of American food to be shipped on US flag vessels, the ability to use Local
} 
It was the 1999 FAC that first allowed associated costs to count towards the fulfilment of the minimum annual commitments. ${ }^{111}$ This possibility was given to reduce tensions between donors who faced high associated costs and those who didn't. For example, between donors covering emergencies in remote areas (such as Rwanda) and having to cover the overland transport from the port of discharge to the border of the recipient country and others who operated in much cheaper operation areas (the transportation costs could not be claimed against the FAC commitments, which were computed exclusively on the bases of the food received by the beneficiary). Allowing donors to count associated costs towards their commitment was also a way to ensure that beneficiaries were not asked to pay for the transport costs of the food donated. A drawback of this provision is that the more is spent on these costs the less will be spent on the assistance itself (yet the convention obligations will be fulfilled).

The 1999 Convention's approach to associated costs exposed one of the major contrasts in aid donations in the nineties, namely the greater attention paid to donors' costs rather than to beneficiaries' food insecurity needs. The new commitment to reduce associated costs is therefore a welcome innovation. Its language however remains vague and more could have been done to ensure associated costs are not unreasonably inflated. For example the Convention could have expressly forbidden Parties to impose conditions that increase associated costs (such as requiring that the food is shipped by nationally registered vessels) or could have inserted a cap above which associated costs cannot be counted towards the commitments.

\section{Beneficiaries of Assistance}

Food assistance can be directed towards eligible countries (which are all countries listed as recipient of Official Development Assistance by the OECD/DAC) and, now, towards eligible vulnerable populations in any such country (Art 4). The inclusion of vulnerable populations in the category of beneficiaries of food assistance is welcome considering the tension and conflicts which sometimes exist between the official Government and vulnerable/minority groups. By selecting vulnerable populations as recipients of assistance the Convention has endorsed the HR argument that people and individuals are the right holders of the right to food. In so doing it has also legitimized the practices of many aid agencies who already provide direct assistance to vulnerable population.

4. Effectiveness of the endorsed obligations.

e) Unfulfilled commitments, information-sharing, monitoring and accountability

As in previous conventions, unfulfilled commitments can be the cause of disputes among Parties. Disputes are resolved by the FA Committee (article 11). However, because the

\footnotetext{
and regional purchase will continue to be constrained'. USGAO, 'International food assistance: Key issues for congressional oversight' (DC, United States Government Accountability Office, 2009)

${ }^{111}$ Art III (f) expressly allowed members to count associated costs towards their commitments. However art III(g) of the 1999 FAC provided that 'in respect of transport and other operational costs, a member cannot count more than the acquisition cost of eligible products towards its commitment, except in the case of internationally recognised emergency situations' such provision is not reiterated in the new convention.
} 
Committee decides by consensus (article 7), any Party, including the Party who has not fulfilled its obligations, can block the adoption of an (adverse) decision by the Committee. ${ }^{112}$ As in previous FACs, no sanctions are foreseen if Parties do not fulfil their minimum annual commitments. ${ }^{113}$ Critics have argued that the lack of strong enforcement mechanisms weakens the Convention's capacity to act as a guarantee for food security and encourages food aid donations to be volatile and pro-cyclical. ${ }^{114}$ While one can object to this criticism by noting that peer pressure can, and has worked well in the past, in resolving members to fulfil their commitments, the lack of sanctions has compromised the public resonance of those complaints.

Although the Convention has not introduced new rules on sanctions, it has strengthened (or attempts to) its peer and public pressure mechanisms. In particular, for the first time, it requires Parties to provide annual reports to the Secretariat on the fulfilment of their obligations. ${ }^{115}$ The reports will be available on a website maintained by the Secretariat and accessible to Parties. ${ }^{116}$

How effective these reports will be in ensuring monitoring of Parties' obligation and enhancing peer and public pressure will depend on the amount and quality of the information available and on the widespread availability of that information. Both elements remain at the moment weak.

For instance, it is unclear what information will be included in the reports and, although guidance is provided by Rule 9 of the Rules of Procedures and Implementations, interpretative gaps still remain. Parties retain considerable discretion on what information to provide as only information strictly related to the quantum of Parties' commitments is to be disclosed, ${ }^{117}$ while information on the quomodo of their commitments (i.e. whether aid is tied, whether the food was monetised etc.) or on the impact of the assistance (i.e. was the assistance sufficient to meet recipients' needs? Did it meet beneficiaries' standards, etc) continues to be optional. ${ }^{118}$ This is unfortunate as it is essential to understand such information if Parties are to meet the Convention's objectives and to enhance the effectiveness of peer pressure. Disclosing such information is also vital for developing best

\footnotetext{
112 Dissent can be expressed at a formal session or within thirty days after the circulation of the minutes of a formal session recording the proposed decisions concerned. Further it needs to be remembered that non-Parties to the Convention -ie. Beneficiaries of assistance or other interested stakeholders such as NGOs- will not be allowed to raise complaints. This is bound to result in fewer disputes being brought in front of the Committee than if beneficiaries were also allowed to raise complaints.

${ }^{113}$ The Convention only requires that 'the unfulfilled amount shall be added to the Party's minimum annual commitment for the following year' unless the FA Committee decides otherwise (art 5.13). As in the past a five per cent cap is imposed on the excess quantities of donation that can be transposed from one year to the next Art 5.14 of the Convention. Thus, if a member contribution in one given year exceeded its minimum annual commitment (for example because of excess food production and/or low prices), no more than five per cent of the excess assistance could be carried forward to the following year.

${ }^{114}$ This issue was first raised against the 1999 FAC. For an extensive discussion of the 1999 FAC see Hoddinott et al (n13).

${ }^{115}$ Although previous conventions encouraged members to exchange information on their food aid programmes and on the fulfilment of their obligations, no systematic mechanisms was in place to sure information was timely shared amongst Parties. See in particular Art XIV of the 1999 FAC.

${ }^{116}$ Art 6 of the Convention. Annual Reports need to be submitted within ninety days of the end of the calendar year.

117 i.e. how much (in quantities of wheat equivalent and/or value) and what type of products/activities are provided

118 The language of Rule 9 is explicit in requiring that only information related to the quantum of Parties' obligations 'should' be included, while all other information 'may' be included in the report.
} 
practices -one of the declared objectives of the Convention. ${ }^{119}$ It seems that the Secretariat is to develop a template to be followed by all Parties but no further information has yet been officially released. On a positive note, it is important that in their reports Parties are now required to describe the circumstances for the failure to fulfil their obligations (article 5.13).

Another point to highlight is that Parties' annual reports are available on a website which is accessible only to other Parties. Non-Parties can only have access to summaries of such reports in the FA Committee's annual report. The Convention does not specify what information the FA Committee's annual report has to include, in fact the content of the annual reports is still a contentious issue within the FA Committee and subject to continuous negotiations. The first two reports by the FA Committee were published in October 2014 and July 2015. Both the 2014 and the 2015 reports include Parties' minimum annual commitments for the preceding year, all expressed in value terms; ${ }^{120}$ they also include a summary of Parties' annual reports (which showcases Parties' major operations and interventions for the year of reporting) and a summary of the activities of the Committee. The 2015 report is more informative than the 2014 report as it contains, for the first time, information on general trends on in-kind food aid, on nutrition interventions, on local and regional procurement. The 2015 report also includes details of legislative reforms taking place in some countries, such as the US, which comply with the Convention, demonstrating that the Convention is having a direct impact on Parties' food assistance policies. However information is still very approximate ${ }^{121}$ and not all Parties disclose details of their food aid operations or provide data on how aid is provided. ${ }^{122}$ These limits notwithstanding, the efforts of the chair of the FA Committee to expand the information included in the annual report need to be praised and welcomed as an important innovation which it is hoped will be maintained and strengthened in the future.

It is evident that limiting the availability of detailed annual reports to Parties only will significantly constrain the role that interested stakeholders, and the public at large, could play as vectors of accountability and public pressure. It is submitted that Parties' annual reports should be widely available so that public accountability and pressure can be enhanced.

Finally, for the first time Parties 'may now propose an assessment of the relevance of this Convention...' (article 16). However, it is unclear how this assessment should be conducted, on what basis and by whom. For example will it be conducted externally? Will it include information on the effectiveness of the Convention (for example if Parties meet their obligations $\left.{ }^{123}\right)$ ? It is too early to know how this provision will be interpreted and whether a Party will ever propose such assessment.

\footnotetext{
${ }^{119}$ Article 2 encourages parties to 'monitor, evaluate and communicate on a regular basis the outcomes and impact of food assistance activities in order to further develop best practices and maximise their effectiveness' 120 The 2014 report expresses commitments for each Party in local currencies only and it does not show the USD equivalent for each commitment making comparisons between donors extremely difficult. Fortunately the problem has been addressed the following year with commitments expressed in both donors' local currencies and in USD.

${ }^{121}$ For example it is reported that in kind products represent approximately $76 \%$ of food assistance provided by FAC members, nutrition intervention to approximately $5 \%$ etc.

${ }^{122}$ Some donors provide more information than others. The US for examples provides data on the percentage of local, triangular and in-kind food aid, of cash transfers and vouchers. Japan, in contrast, does not provide any such information. Other Parties only provide limited and selective information, for instance it is mentioned in the summary report for Switzerland that in 2014 Switzerland donated Swiss dried skimmed milk as in-kind food aid which is indicative that Swiss aid was tied.

${ }^{123}$ See for all criticism of previous FAC and suggestions for reforms by Hoddinott et al (n13)
} 
No other monitoring mechanism is provided by the Convention. ${ }^{124}$ As with the previous conventions no regular and systematic assessment of Parties' obligations is conducted by the FA Committee or by any external Body to verify that Parties have complied with their obligations. ${ }^{125}$

In conclusion, the Convention places greater emphasis than ever before on enhancing information-sharing, transparency and monitoring. By requiring Parties to publish annual reports on the way they have fulfilled the Convention objectives and principles it has introduced an unprecedented mechanism to enhance transparency and reinforce the role that peer and public pressure could play in ensuring that members respect their obligations. Besides, peer and public pressures could relive Parties from political pressure exercised at the national level by the potent lobbies that gain from food assistance and should therefore be encouraged. However, it remains so far unclear what information the Convention new transparency mechanisms will contain and how accessible they will be for non-Parties and for the public. In order to ensure that these mechanisms work, data on the status of Parties' implementation of the Convention need to be transparent and easily accessible to donors and beneficiaries, to practitioners and to the public at large.

\section{AN UNEXPECTED TWIST: THE REFERENCE TO THE WTO}

During the process of negotiating the Convention, questions were raised concerning the opportunity to strengthen the links between the Convention and other international institutions also dealing with aid, food aid and more generally food security. For example, discussions had started over whether to move the FAC secretariat to Paris, under the remit of the OECD/DAC, ${ }^{126}$ or to move it to Rome where the FAO and the WFP could have staffed a joined secretariat for the FA Committee, the CSSD, and WFP/INTERFAIS. ${ }^{127}$ Others suggested that reinforced cooperation lines should have been developed between the FAC and the newly established Committee on World Food Security. ${ }^{128}$ However, these suggestions have not been taken up by the negotiators and the institutional settings of the Convention

\footnotetext{
${ }^{124}$ The UN Special Rapporteur on the right to food, Professor Oliver De Schutter, also indicated that one way for improving the monitoring systems within the FAC and ensure that donors do not violate recipients' right to food, would be to recur to external observers. See O. De Schutter ( $\mathrm{n} 83$ )

125 In contrast for example the OECD/DAC Recommendation on untying aid to LDC and HIPC reserves to the $\mathrm{OECD} / \mathrm{DAC}$ committee the role of monitoring and evaluating "all aspects" of the agreement, via three mechanisms: the Annual Reports, the Peer Reviews of individual DAC Members, and a "comprehensive evaluation" on the effectiveness of the Recommendation to be published periodically. A similar approach could have been followed under the Convention.

${ }^{126}$ This solution was advocated to improve the overall transparency of food assistance and align food aid policies to those adopted for aid in general See E Clay 'A Future Food Aid or Food Assistance Convention?' (Overseas Development Institute Background Paper 6, June 2010) (http://www.odi.org.uk/resources/download/4941.pdf). The major disadvantage of this proposal is that the OECD is donors-driven so the agreement would remain a donors' club. Further some FAC members are not $\mathrm{OECD} / \mathrm{DAC}$ members (such as Argentina) therefore special arrangements would need to be put in place. To this end Clay suggests the establishment of a DAC-plus group.

127 This would have enabled to gain from the specialised expertise of these institutions and to better coordinate the work of the various bodies dealing with food assistance.

${ }^{128}$ see Clapp and Clark (n 1516) who argue that 'Relocating the FAC to a Rome-based structure linked to existing UN bodies would resolve many governance input issues, but it is likely that the current member-state donors of the FAC would not be comfortable giving recipient countries and civil organizations any say in negotiating their food aid commitments' (footnotes omitted).
} 
remained unchanged with the Convention's Secretariat based in London and housed by the committee on surplus disposal. ${ }^{129}$

The relationship between the Convention and those institutions such as the FAO, the WFP, the CSSD, that historically have dealt with food insecurity, have left unchanged by the Convention, which continues to operate distinctively from those institutions -coordination and collaboration is limited, as discussed above, to the possibility of inviting those institutions as observers to the meetings of the FA Committee. Instead, a significant change has been introduced in respect to the Convention's relationship with another prominent international organisation, namely the WTO. Breaking from the past, the Convention now makes explicit reference to the WTO obligations. In the preamble it affirms Parties' determined intention to 'act in accordance with their WTO obligations' (preamble) and, most significantly, in Article 3, titled Relationship with the WTO Agreements, specifies that:

'nothing in this Convention shall derogate from any existing or future WTO obligations applicable between Parties. In case of conflict between such obligations and this Convention, the former shall prevail. Nothing in this Convention will prejudice the positions that a Party may adopt in any negotiations in the WTO (emphasis added).

It was mentioned in the first section that negotiations for renewing the 1999 FAC were postponed to await the conclusion of the WTO Doha round of negotiations. ${ }^{130}$ When these negotiations stalled negotiations for a new FAC resumed and the Assistance Convention was adopted, but the WTO continued to cast an important shadow on the Convention.

Article 3 certainly reflects the international background under which the Convention was negotiated and adopted, i.e. the WTO negotiations had not been concluded yet and Parties did not want to hamper their negotiating positions within the WTO development round. ${ }^{131}$ Possibly without this clause the Convention would not have been adopted. This provision also signals that the problems raised by the trade-distorting effects of food assistance continue to be a major issue for Parties and that the WTO is the preferred forum to solve those issues. Yet article 3 could have significant implications for the regulation and the governance system of food assistance, implications that go beyond safeguarding parties' negotiating positions within the WTO. Indeed, by proclaiming the supremacy of WTO rules over those of the Convention, article 3 changes and inverts the previous relationship between the FAC and the WTO: while in the past it was for the WTO to refer to the $\mathrm{FAC}^{132}$ and to recognise the

\footnotetext{
${ }^{129}$ Coordination with other international institutions is maintained in the limited form of granting observer status to other international organisations willing to participate to the FA Committee meetings (see above).

${ }^{130}$ The WTO negotiations started in 2001 and are built upon three main categories (or pillars): market access aimed at reducing tariffs for agricultural products and reaching agreements on opening up trade in agriculture for products currently not covered by the agreement; domestic support-aimed at the elimination of subsidies to national farmers; and export competition-aimed at the elimination of any form of subsidies for the export of national products. Negotiations on food aid are taking place within the export competition pillar which also includes direct export subsidies, export credits, state trading enterprises and food aid. Hence, the WTO negotiations on food aid are closely interrelated with the negotiations taking place in other sectors of the AoA. See J Clapp, 'WTO Agriculture Negotiations: Implications for the Global South' (2006) 27 Third World Quarterly 563 and also Clapp (n 5)). C Hanrahan and C Canada, 'International Food Aid: U.S. and Other Donor' (Congressional Research Service, 2011)

${ }^{131}$ Parties to the Assistance convention are also WTO members

${ }^{132}$ For example Art 10 of the WTO Agreement on Agriculture see above ( $\mathrm{n} 9$ )
} 
importance of its rules, the Convention's provisions are now subordinated to the WTO, assigning a new hierarchy to the rules of the two agreements.

What is also especially surprising is the fact that the Convention does not limit the supremacy of the WTO provisions to conflicts that might arise on the trade-related aspects of food assistance (and so between the rules in the Convention that deals with the trade-related aspect of food aid and the same rules in the WTO) but it extends the supremacy of the WTO to any conflict that might arise between the Convention's and the WTO's rules, thus potentially also including non-trade related aspects of food aid (for example those strictly related to humanitarian/food security issues). What are the implications of such an inverted hierarchy and the consequences on the Convention's objectives? Could they be jeopardised by the supremacy of the WTO provisions?

Proclaiming the supremacy of WTO rules over the Convention's rules could open a Pandora's Box of questions and problems linked to criticisms often raised against the WTO. The WTO has been blamed for being disproportionately geared towards the economic and trade interests of its developed country members ${ }^{133}$ and for not taking sufficiently into account developing countries' developmental and human rights concerns. ${ }^{134}$ These issues are especially contentious in the context of the WTO Agreement on Agriculture whose provisions have been regarded as an unfortunate compromise between the different and complex interests at stake within the agricultural sector. ${ }^{135}$ The complexity of such conflicts, and the tension and contrasts which persist between WTO members in this sector, is confirmed by the difficulties encountered during the negotiations for the renewal of the agreement negotiations which to date have not been concluded and which remain a major obstacle to a satisfactory conclusion of the WTO Development Round. However, reaching the conclusion (solely on the base of this criticism) that article 3 is a negative and unnecessary innovation brought about by the Convention is premature. ${ }^{136}$ The negotiations for the renewal of the

\footnotetext{
133 This criticism has not been sedated despite the 'development agenda' became a top priority for the WTO Doha round of negotiations and the 'promotion of development' the 'core business of the multilateral trading system', P Subedi, 'The Road from Doha: the Issues for the Development Round of the WTO and the Future of International Trade' (2003) 52 International and Comparative Law Quarterly 425; Y-S Lee, Reclaiming Development in the World Trading System (Cambridge University Press 2007). R H Wade, 'What strategies are viable for developing countries today? The World Trade Organization and the shrinking of 'development space", (2003) 10(4) Review of International Political Economy 621; S Devadoss, 'Why do developing countries resist global trade agreements?' (2006) 15 The Journal of International Trade \& Economic Development 191; D Alessandrini, Developing Countries and the Multilateral Trade Regime: The Failure and Promise of the WTO's Development Mission (Hart 2010).

${ }^{134}$ See for example exponents of the so-called 'trade and debate' or 'trade linkage' debate. In particular P Nichols, 'Trade without Values' (1996) 90 North-western University L. Rev 658; R Howse and M Mutua, 'Protecting Human Rights in a Global Economy: Challenges for the World Trade Organisation' (international Centre for Human Rights and Democratic Developmen, Policy Paper, 2002). The frame of this criticism has been challenged in recent years and a new interpretative model has been proposed to engage with the debate over the objectives and scope of 'free trade,' of the WTO and with the fundamental question of 'what free trade can and should mean' See A Lang, 'Reflecting on Linkage: Cognitive and Institutional Change in the International Trading System' (2007) 70(4) Modern Law Review 523, and A Lang World Trade Law after Neoliberalism: Reimagining the Global Economic Order (Oxford University Press, 2011).

${ }^{135} Y$-S Lee (n 132) at 107-114.

${ }^{136}$ One of the criticisms raised by Lang towards the 'trade and' debate is that '...it is precisely this construction [of labour as a 'non-trade issue'] which the linkage debate tends to perpetuate, by treating the conceptual separation of 'trade' and 'labour' issues as self-evident, natural and given. The debate perpetuates a conceptual framework within which arguments of the kind Ruggiero proposes [ie the WTO cannot drift away from its trade
} 
AoA have not been concluded and it is too early to know what conflicts, if any, might arise between the Convention and the new AoA, and how they will be solved. On the contrary, it could be said that the presence of article 3 in the Convention brings to the fore the intertwined nature of these two systems of norms (ie the FAC and the WTO) and the necessity to initiate a dialogue between these two institutional fora. Furthermore, when (and if) the process of the WTO negotiations on agriculture will be resumed, awareness of the new WTO 'supremacy' over the Convention's rules might put pressure on WTO members who are Parties to the Convention to have regard for the Convention's food security objectives and to ensure that the Convention's objectives are respected and not undermined by the WTO rules. Ultimately, this could instigate a more constructive debate on how to address food security within the WTO if only by engaging more commentators and actors in this debate. ${ }^{137}$ This dialogue will be further strengthened by the fact that the WTO's governance system is, differently from the Convention, inclusive of developing countries who will also have the chance to influence the WTO policies on food aid.

What shape the WTO policies will take remains to be seen. The WTO negotiations on food aid are still substantially 'open' if one believes that a new WTO agreement on agriculture will ever be agreed. In Bali, at the ninth WTO Ministerial Conference (December 2013), WTO members failed to adopt any new measure on food aid. ${ }^{138}$ Until a new agreement is adopted the Convention remains the principal international legal instrument to regulate food assistance.

\section{CONCLUSIONS}

The adoption in 2012 of the Food Assistance Convention is the first major attempt to modernise the rules applicable to international food assistance and to address the criticism raised against the previous architecture of food aid regulation. More than any convention before it, it places food security at the heart of Parties' obligations. The message delivered by the Convention is powerful: food security interests should prevail when devising the modalities for granting assistance and should always guide Parties' actions on food assistance. Better than any convention before, it enhances the role played by beneficiaries and by nonParties to the Convention, it goes beyond the mere specification of minimum commitments

vocation and cannot offer solution for non-trade issue] are persuasive and are deployed to legitimise the current shape of trading institutions.' See Lang (n 133). Following this it could be argued that one should not frame the discussion on article 3 of the Convention in terms of supremacy of trade over food security.

137 Food security has mainly been dealt by institutions within the UN system. Food security experts have reluctantly engaged with the WTO literature. Article 3 has brought to the attention of the FA Committee, of the Parties of the Convention and of all food security and food aid commentators, the importance of WTO rules for food security, now requiring engagement with those rules.

138 See above (n19). The 2008 modalities on agriculture at art 10.4 dealt extensively with the trade-related aspects of food aid, proposing stricter rules to prevent WTO members using food aid as an export tool. In Bali WTO members focused instead solely on transparency of food aid donations, the Draft Ministerial Declaration on the export competition pillar of the AoA, agreed on 3/12/2013 titled Elements for Enhanced Transparency on Export Competition requires WTO members to provide the following information on food aid: '1. Product description; 2. Quantity and/or value of food aid provided; 3. Description of whether food aid is provided on inkind, untied cash-based basis and whether monetisation was permitted; 4. Description of whether in fully grant form or concessional terms; 5. Description of relevant needs assessment (and by whom) and whether food aid is responding to a declaration of emergency or an emergency appeal (and by whom); 6. Description of whether re-export of food aid is an option under the terms of the provision of food aid.' 
of food aid donations to include extensive principles and rules on the way the assistance should be donated. The Convention sets clear commitments to make the assistance adequate, suitable and effective to meet beneficiaries' needs and to minimise the potential distortive effects of food assistance imposing strict boundaries on the use of the assistance as a means of export promotion. Doubts no longer exist on what the best approach to enhance the effectiveness food assistance is and how Parties should grant that assistance. The expansion of its coverage, from quantum to quomodo of Parties' obligations, has bolstered the Convention's importance. The Convention is the manifesto of food assistance; it sets benchmarks for all donors to follow when providing food assistance and is relevant when assessing donors' performance. Following the stream of its predecessors, the Convention breaks with the legal lassaiz-fair that characterises the aid sector in general and the assumption that aid is a charitable activity and donors can freely choose what, if and when to donate.

However, as explained above, the Convention is far from being a perfect agreement. Problems still persist with many of its provisions and in particular with its monitoring and review mechanisms. The Convention remains weak when called to warrant that Parties fulfil their commitments. The role played by interested stakeholders and by the public at large should be enhanced so that pressure can be exercised on Parties to respect their obligations. ${ }^{139}$ The way Parties set and can now modify their commitments on a yearly basis should also be reformed and Parties should be required to make multiyear commitments so that predictability of food resources can be ensured (for a summary of the major issues see Table 1).

Yet notwithstanding the problems identified here, the Convention remains a vital instrument to ensure food security for all. The Convention, like the FACs before, sets principles, rules and obligations that are legal in nature and for which Parties can be held accountable. ${ }^{140}$ In its absence, states' obligation to assist countries in need remains (almost entirely) at their discretion. The Convention is the only agreement that addresses the many facets of food assistance and this is likely to remain the case for a long time to come given the slow pace at which work on food aid is progressing in other fora. The failure of the WTO negotiations in Bali to reach a conclusive agreement on food aid and to reform the WTO Agreement on Agriculture is an example of this.

The Convention is the only legal instrument that makes donors accountable for their donations and for the way they fulfil the right to food. The reticence of some States to ratify the Convention (especially of those states that have previously been members of the 1999 FAC) is questionable and should be read as a backwards step in the quest to enhance the effectiveness of food assistance.

\footnotetext{
${ }^{139}$ However this is not to say that the Convention is not binding amongst its Parties. The Convention is a formal international agreement -signed and ratified by its Parties- and it has the legal status of a binding international agreement. Parties who do not fulfil their commitments violate their international obligations, but the lack of appropriate dispute resolution and monitoring mechanisms weakens the force and credibility of the commitments endorsed. On the legal status and implications of the lack of monitoring and enforcement mechanisms of international agreements see Andrew T. Guzman, 'The Design of International Agreements', The European Journal of International Law (2005), Vol. 16 No. 4, 579-612

${ }^{140}$ See Clapp (n 5) and De Schutter (n 4)
} 